\title{
CULTURA GENÉTICA vertigem ontológica e dissolução do conceito de "natureza"
}

\author{
Luiz Felipe Pondé \\ Filósofo, Professor do Programa de Estudos Pós-Graduados em Ciências da Religião da PUC-SP
}

\begin{abstract}
Resumo: O objetivo do artigo é discutir o processo psicossocial em curso no momento em que se instala a nova tecnologia genômica, processo que cria uma ruptura ontológica na cultura ocidental - à semelhança de outras rupturas, como a passagem do nomadismo caçador-coletor ao sedentarismo da agricultura -, identificada como dissolução do conceito de natureza e o horror ontológico que este fato implica. Tal dissolução será concretizada pela banalização "feliz" do consumo em larga escala dos bens genômicos, um comportamento de consumo, na realidade um desdobramento da aposta iluminista na emancipação humana que se artificializa definitivamente na matéria viva, normatizando-a dentro da categoria de insumo.

Palavras-chave: tecnologia genômica; natureza e cultura; ciência e religião.
\end{abstract}

“O padrão social de controle da área a que nos referimos como 'eventos naturais' é bastante elevado nos países industrializados, e o mesmo se aplica ao autocontrole do pensamento e da observação neste campo. Nele, a insegurança das pessoas diminuiu expressivamente no decorrer dos últimos séculos, tal como aconteceu com o componente de desejo e medo na atividade mental nessa esfera. Mas em relação às vastas áreas do mundo humano, especialmente a suas tensões e conflitos, tanto o padrão de controle social sobre os acontecimentos quanto os de autocontrole na reflexão sobre eles são consideravelmente menores. As ameaças mútuas das pessoas e, particularmente, das nações, bem como da insegurança daí decorrente, ainda são muito grandes, e o refreamento dos afetos na reflexão sobre essa área é reduzido, comparado ao que é normal em relação aos fenômenos naturais." (Elias, 1994:87).

O historiador das religiões, o romeno Mircea Eliade (1978), mostrou que a passagem da cultura de caçadorescoletores para a agricultura envolveu toda uma alteração do campo religioso humano. Sendo as religiões, segundo o mesmo Eliade, modos criptoontológicos de pensamento, transformações religiosas implicam necessariamente abismos ontológicos desconhecidos. As divindades que habitavam e moldavam o real do homem e da mulher nômades carregavam em si as formas que estes mesmos homens e mulheres imaginavam ser as qualidades necessá- rias pressupostas na condição nômade (agilidade, força, velocidade, habilidade em se fazer invisível, enfim, formas superiores de movimento e deslocamento no espaço) para superação da condição humana essencial, ou seja, o constante terror da contingência manifestado no pavor estrutural do ser humano diante da sua evidente fragilidade em oposição ao poder absoluto da Natureza ou do Cosmo. À intratável corrupção física humana, o cosmo revela sua tranqüila e ativa permanência em si mesmo, opondo desta forma seu ser ao nosso miserável não-ser. Com a passagem à agricultura e ao sedentarismo, os seres humanos descobrem outras divindades, agora carregadas dos valores necessários para a manutenção da vida na ausência de deslocamento espacial, isto é, divindades que representavam as necessidades "técnicas" para se agir sobre as recém-descobertas "leis da natureza" específicas, percebidas pela observação dos modos naturais de reprodução da vida vegetal. O sol, a lua e seus ciclos, o fluxo das águas e seus poderes sobre a terra cultivada, passaram a manifestar o domínio do Sagrado (o Absoluto agente) e assim, apontavam para os modos de nos "defender", talvez, de nossa estrutural miséria ontológica. O escritor e explorador inglês Bruce Chatwin (1997), praticando o que poderíamos chamar de uma antropologia social histórica minimalista, também chamou a atenção para os desdobramentos (para ele, defensor do nomadismo, infelizes) decorrentes da mesma transformação radical de hábitos hu- 
manos básicos. O sedentarismo e seu necessário conservadorismo geográfico envolveu o abandono do movimento contínuo e cíclico dos seres humanos, acarretando decrepitudes física, psicológica e social desconhecidas para os nômades. Os exemplos se multiplicariam: degeneração muscular e neuronal precoce devido à ausência de estímulos constantes e novos aos neurotransmissores, empobrecendo o arco-reflexo e a amplitude motora, obstruções vasculares cada vez mais rápidas pois o alimento, sem movimento contínuo, se transforma necessariamente em veneno, levando o sedentário à ridícula criação do movimento muscular estéril do ponto de vista da função motora, conhecido como "ginástica", depressões e tédios constantes em virtude da monotonia estética do espaço residencial e da pobreza cognitiva associada, levando o homem e a mulher a se entregarem à risível aventura da invenção da distração e da decoração programadas, aos exageros da atividade reprodutora como "resto" da prática física permitida, a patologia social de comparação e acúmulo de bens materiais (agenciadores psicossociais da inveja e ancestrais primeiros do capitalismo) impossível ao nômade pelas necessidades naturais do movimento contínuo, a produção crescente de lixo acumulado e geometricamente multiplicado pela mesma mania de acúmulo de bens (estes e o lixo seriam "primos" sociais e, portanto, teriam a mesma raiz funcional), enfim, à inflação da dimensão estática daquilo que chamamos "hierarquia social". Assim sendo, com o sedentarismo, inaugura-se o império da inércia patogênica e das grandes agonias sociais.

São vários os campos de estudo que se ocupam com os infinitos desdobramentos associados aos modos de vida e às atividades produtivas da espécie humana. Os poucos exemplos acima ilustram a amplitude do campo de problemas que demandam uma reflexão detida. A variação desses modos e a verticalidade das transformações antropológicas causadas por tal variação se desdobram nas mais diversas áreas: da religião à ontologia, da fisiologia aos hábitos de comportamento, da sociedade à política. Como caso específico dessa variação - aliás, foco de interesse nesta rápida reflexão -, a prática generalizada da biotecnologia genética (os usos e recursos da genômica), a face contemporânea de Prometeu, tenderá a assumir, deste ponto de vista, a mesma amplitude que a revolução da agricultura e, portanto, nos encontramos às margens de um abismo ontológico (psicológico e social) de dimensões gigantescas. Em meio ao ruído sempre histérico e quase sempre efêmero da mídia, o que se esconde é o medo atávico do risco estrutural que acompanha as conquistas da atividade cognitiva, reflexiva e técnica do ser humano. ${ }^{1} \mathrm{E}$ mais, os textos técnicos sobre o tema pouco ajudam a compreensão das transformações envolvidas na futura e provável banalização dos produtos da genômica. ${ }^{2}$ As discussões éticas também pecam pela "ingenuidade cínica"3 pois facilmente escamoteiam o caráter de emancipação que o consumidor verá na genômica e que forçosamente levará ao uso dos recursos biotecnológicos em escala semelhante aos usos da agricultura.

Assim, a tentativa de compreensão dos campos de possibilidades e de pavor que geram a genômica de consumo fica limitada a discussões pouco proveitosas e "mistificadoras", e acima de tudo de muito pouco valor para uma ampliação da capacidade do "senso comum" pensante para compreender e se comprometer com o profundo processo de mutação antropológica em curso.

A produção filmográfica sobre o tema ficção científica (science fiction), apenas como introdução, pode nos servir como indicador interessante da visão atual de como poderão acontecer os desdobramentos do consumo sistematizado da genômica, que seguramente será introduzido pelos interesses do capital associado à face contemporânea de Prometeu. Entre os filmes mais recentes e de maior público, a produção Blade Runner de Ridley Scott (1981) introduz a análise mais importante dos fundamentos do "choque" genômico: a relativização das supostas diferenças que existiriam entre seres humanos naturais e artificiais. O que se esconde por trás da luta pela sobrevivência que leva a cabo os "replicantes" (os homens e mulheres artificiais) diante de seu criador cientista é a dissolução tema fundamental que será novamente abordado - do conceito de natureza, ${ }^{4}$ transformação ontológica que causará a decadência dos vocabulários naturalistas nos quais ainda estamos incluídos. Segundo o filósofo pragmático Richard Rorty, assistimos nas últimas décadas à falência dos vocabulários teológicos (Rorty, 1992), que causou a perda de valor cognitivo - e com ele, qualquer possibilidade de significado, inclusive ético ou moral - de qualquer argumento racional baseado em fundamentos religiosos. Como exemplo da estranheza causada por esse processo de falência de uma rede específica de vocabulários, podemos mencionar as "absurdas" discussões sobre a humanidade (ou não) dos chamados índios concluídas pelos intelectuais espanhóis e portugueses na seqüência das grandes descobertas marítimas. O paradigma mental e filosófico desses debatedores era christian-oriented e portanto o choque da nudez dos índios associado a similaridade com os humanos justificava a controvérsia: como 
descendentes de Adão e Eva podiam andar nus? Onde estava neles a marca hereditária (no caso em particular, a noção de privacidade vergonhosa do corpo) do pecado original? Para além da completa validade específica ou não da argumentação rortiana, é evidente a decadência dos modelos teológicos de pensamento - claramente fora dos ambientes mais marcadamente religiosos - e portanto me parece consistente a analogia: penso que um tal processo se dará pelo valor cognitivo dos termos sobre o conceito de natureza (ou nature-dependent). Outro tema introduzido pelo filme é a "dúvida cética de formato cartesiano" (Descartes, 1983) no que diz respeito à certeza da própria identidade: como ter certeza da própria identidade se a memória, via manipulação de sua base (sua verdadeira natureza) bioquímica, poderia ser na realidade fruto de um "gênio maligno" - o engenheiro molecular - que aí introduzia dados até então inexistentes? O drama da identidade natural aqui se impõe.

Outro filme que vale a pena mencionar, mais recente, é Gattaca de Andrew Niccol (1997). Interessante observar as relações sociais e jurídicas nele esboçadas: a associação entre patrimônio (logo diremos "capital") genético e os mercados de trabalho e amor (afetos) e a preocupação do poder legislativo, ainda que de modo fatalmente cínico, de criminalizar o "genismo", ou seja, a prática social leviana da discriminação baseada nos diferentes patrimônios genéticos - o Estado (leia-se, o Mercado) teria, é claro, o monopólio da violência discriminatória genômica legítima. Ainda com relação a esse filme, importante seria mencionar seu happy end, no qual a integridade pessoal e seu poder é salva como possibilidade que ultrapassa o determinismo genético, figurada na vitória do "filho do acaso" (miserável geneticamente) sobre seu irmão manipulado. ${ }^{5}$ Idealização vaga e infantil de que algo maior que o patrimônio genético, associado a um meio ambiente devorado e moldado pela sistematização social e política dos recursos genômicos, existiria e permaneceria como fundamento último de um livre-arbítrio (sobrenatural porque "sobregenético") humano que agora, em vez de lutar contra os desígnios opacos de um Deus absconditus, lançar-se-ia à luta contra os desmandos da engenharia genética e sua lacaia, a sociedade genista. Típico manifesto cínico que falsamente ensaia a fuga (e recusa) do terror ontológico instituído pela sociedade baseada no consumo sistemático e legítimo de bens genômicos.

Outro marco fundamental e exemplificador das controvérsias filosóficas com relação à genética de consumo - e que me servirá para introduzir o modo de reflexão que se julga consistente sobre os efeitos da banalização da genômica pelo mercado livre de seus recursos - é a recente polêmica entre os filósofos alemães Peter Sloterdijk e Jürgen Habermas. ${ }^{6} \mathrm{Na}$ seqüência da leitura e posterior publicação de seu texto "Regras para um parque humano - Uma resposta à carta de Heidegger sobre o Humanismo" na Alemanha, em um evento dedicado ao filósofo alemão Martin Heidegger, Sloterdijk foi violentamente acusado - por Habermas e outros intelectuais - de retomar irresponsavelmente a "palavra eugenista" em solo alemão. Não nos interessa aqui especificamente o curso da controvérsia e suas particularidades históricas alemãs, mas parece razoável a idéia de que se alguém, não um alemão, introduzisse uma reflexão semelhante a Sloterdijk, o "halo" do terror e da paranóia nazista seria seguramente menor. ${ }^{7}$

Evidentemente que o imaginário contemporâneo está pleno de referências ao aparentemente enorme grau de parentesco ideológico entre a manipulação programada dos seres humanos e o projeto nazista, e tal fato, aliás, como reconhece o próprio Sloterdijk, é fundamental na atitude cínica que a sociedade humanista assume diante da prática genômica: reprime histericamente, por discursos éticos rasos, a aceitação - em nome de uma emancipação que tem medo de revelar seu próprio nome - da genômica, a fim de concluir a revolução genética em silêncio e sem o barulho indesejável da sociedade aterrorizada, que se trabalhado poderia se transformar em um processo de conscientização política da dimensão da revolução em curso. $\mathrm{O}$ cinismo aqui é exatamente essa recusa pública de um tipo de reflexão que produz o desconforto moral necessariamente presente na forma bem-sucedida do projeto humanista ocidental, a biotecnologia, via manifestos pretensamente "éticos" mas que na verdade não enfrentam, na prática privada, o irresistível desejo humano de combater sua miséria ontológica estrutural - presente na evidente e terrível corrupção da matéria viva e muito ativo na luta de muitas mulheres, por exemplo, contra o envelhecimento pelas "delícias" estéticas da prática alegre de automutilação gerenciada pela moderna medicina plástica. Segundo Sloterdijk, na sua cadeia de argumentos que parte de Platão e sua "República" de sábios que "pastoreiam" o "resto humano", em meio à falência das engenharias sociais e políticas entre os séculos XVIII e XX, surge a práxis genética como verdadeira descendente vitoriosa do projeto ocidental de aperfeiçoamento ontológico da espécie. ${ }^{8}$

Diante disso, seguindo os passos da reflexão de Sloterdijk, devemos passar urgentemente à legislação nãocínica de tal processo abissal. O remédio contra a refle- 
xão cínica seria exatamente a atitude intelectual que assume o mal-estar e encara o abismo ontológico no qual estamos prestes a mergulhar, fruto do próprio projeto de emancipação que caracteriza as "melhores almas" no Ocidente. Genômica não é na sua raiz delírio nazista, ainda que a ele tenha servido, mas o resultado do desejo do homem e da mulher ocidentais na sua luta interminável contra a natureza devoradora e seu Criador. Tal reconhecimento em absoluto pressupõe a institucionalização de um novo e ingênuo "14 juillet" para celebrar a queda da última Bastilha, a natureza, esta senhora caprichosa, mas sim a fundação de uma reflexão que parte da assunção do seu "objeto de desejo" com nome próprio, ou seja, a liberação do ser humano de qualquer forma de limite imposto à sua capacidade técnica e reflexiva de moldar seu próprio destino, seguindo a trilha baconiana de controle e submissão da natureza com o objetivo de melhorar suas condições de vida.

A reflexão aqui, de certa forma, em muito se aproxima da "defesa de Adão" mencionada por John Milton na sua obra Paradise Lost: "transgredidos os limites impostos por Deus, que legislemos livremente sobre nosso jardim da des-graça" (Milton, s.d.). Poderia se dizer que este é o primeiro "halo" que na realidade paira como éter sobre o pensamento quando se trata de encarar o drama ontológico causado pela genômica. Nesse sentido ela reedita os mitos adâmico e prometeico na sua forma mais violenta, e retomando a equação proposta por Eliade, isto é, "religião é criptoontologia", a relação entre a genômica e os universos míticos ocidentais que narram a desmedida humana aponta para as profundas ressonâncias religiosas que se impõem quando se trata de analisar detidamente a cultura e os hábitos de consumo que estão por surgir. Todavia, em uma primeira apreciação, não parece que a religiosidade oportunista de raiz instrumental e narcisista que caracteriza a retomada espiritual no final do milênio apresente muita resistência ao consumo dos recursos da genômica, pelo contrário, rapidamente deverá produzir alguma lenda periférica que justifique a libertação espiritual pelo aperfeiçoamento dos "genes imateriais". ${ }^{9}$ As bravatas oficiais ou canônicas contrárias à genômica deverão seguir o curso normal das proibições ao uso de preservativos. Não penso que os desdobramentos mais interessantes se darão neste terreno da religiosidade explícita. As ressonâncias religiosas a que se fez referência anteriormente, ainda que certamente possam causar angústias legítimas de cunho religioso institucional em alguma parcela da população, apontam mais especificamente para o conteúdo ontológico latente da equação eliadiana (devido ao pavor que experimentamos diante da nossa desgraçada estrutura ontológica).

Parece, portanto, que deveríamos dar mais atenção ao eixo propriamente ontológico do problema e, neste sentido, uma rápida reflexão sobre o motto no início deste percurso seria de grande ajuda.

Segundo o que nos diz Elias, haveria uma redução acentuada nos pavores mentais sobre a prática das chamadas ciências naturais e a reflexão produzida sobre tal prática nas sociedades industrializadas, ${ }^{10}$ ao passo que, no campo dos conflitos sociais e de sua necessária reflexão, esses pavores mentais permaneceriam ativos em virtude da falta de segurança (antes de tudo, epistemológica) existente aí, em oposição à segurança com relação ao controle intelectual sobre o universo dos "objetos naturais". A reflexão de Elias aqui, evidentemente, se insere na sua preocupação sobre a presença dos padrões "mistificadores" e da ingerência dos afetos (ansiedade, insegurança, etc.) no campo da epistemologia aplicada às ciências sociais (ou às ciências em geral), o que desenharia o círculo vicioso do pavor mental inviabilizando uma prática mais efetiva de objetividade no lidar com os "objetos sociais". A reflexão de Elias situa o problema de modo bastante esclarecedor, ainda que evidentemente partindo de outra trama de conceitos e girando ao redor de outra gama de temas. A tentativa de descrição do processo de dissolução do conceito de natureza não deixa de ser um percurso conceitual que muito se aproxima da batalha de Elias contra a força aglutinadora, porém infeliz, de um ponto de vista cognitivo e epistemológico dos "fantasmas" dos produtos reificados do chamado intelecto - ele mesmo, uma reificação de uma função do sistema nervoso humano materializada no espaço social - sobre a atividade reflexiva humana ao longo da história da filosofia e das ciências, história que se coloca como um ato específico dentro do drama geral no Ocidente que chamaríamos, ainda seguindo Elias, de "o processo civilizador". A tensão entre cultura e natureza é exatamente um dos modos pelos quais podemos descrever o devorar do natural pelo cultural.

Por dissolução do conceito de natureza entende-se um longo movimento da cultura ocidental que, com o advento da biotecnologia, mais especificamente a genômica e sua engenharia, terminará por produzir a decadência da tensão citada, porque será normal a idéia segundo a qual aquilo que se chamava natureza passa a ter apenas o estatuto de matéria-prima bruta da atividade biotecnológica avançada - não existe tensão ontológica alguma entre os carros e o 
petróleo mas sim meramente procedimentos técnicoambientais e de produção. Tal processo envolverá a gradual perda de significado cognitivo (ainda que não-poético) dos vocabulários que têm seu eixo na idéia de natureza - que revelará desse modo sua real condição de "objeto reificado" desmontado pela genômica de consumo - e, como desdobramento, esvaziará toda e qualquer articulação racional que tentar fazer uso desses vocabulários como fundamento de práticas social, lógica e psicológica baseadas na tensão já referida. Todo esse processo recoloca o estranhamento e o desconforto na atividade reflexiva tal como Elias fazia referência na citação anterior.

Esse processo se dá em um universo materialista que, ao contrário do que se pensava, foi o verdadeiro agente da mais radical experiência de transcendência produzida até então: com a biotecnologia encontramos, e vamos alargar, a brecha do Ser. Por que "transcendência"? Porque o Ser, ou seja, a matéria (viva) passa a ser submetida aos procedimentos (meramente) humanos de produção e sofisticação. A civilização ocidental agora lança suas garras sobre a matéria viva, organizando-a da melhor forma possível do ponto de vista da cultura. ${ }^{11}$ Transcendência porque ultrapassa-se (ou pelo menos reduz-se radicalmente) os padrões de sentido da matéria viva exclusivamente definida até então como a tensão onde a natureza seria o pólo que resistiria por definição à cultura. A natureza não é mais o outro da cultura.

O que prepara o processo de "civilização da matéria viva" é o relativismo ${ }^{12}$ que se instala em seu seio. Por meio dele, a dimensão de ansiedade retorna ao trato com os objetos naturais porque os revela enquanto objetos da cultura e, assim sendo, volta a situá-los enquanto "objetos sociais" inseridos em um mar de intenções construídas social e psicologicamente, por exemplo, as diferenças (meramente) econômicas são redefinidas em termos biotecnológicos e portanto se dissolvem no mar do relativismo ontológico, revelando sua face mais violenta enquanto intratável equivocidade moral - quem não tiver acesso às técnicas de manipulação será entregue aos desmandos da natureza precária e selvagem, o "divino" acaso -, pois a espessura da miséria social será mais do que nunca também de espessura biológica. A reflexão a partir da biotecnologia genética é revisitada pelos pavores humanos, mas na sua modalidade lovecraft: o terror do abismo ontológico e da ausência de referências universais extra-humanas (ou sobre-humanas) consistentes. $\mathrm{O}$ corpo torna-se humano, demasiadamente humano. $\mathrm{O}$ relativismo forte, produto da mente praticante do ceticis- mo, é usualmente compreendido como o rochedo contra o qual se despedaçam todas as formas de universalismos em virtude da falta de critérios últimos e insuperáveis: a (duvidosa) escolha humana torna-se agente da definição dos parâmetros de sentido na organização genista da matéria viva, e o sentimento de vertigem aproxima-se da condição de um barco à deriva, sem cais. A matéria (o Ser) é definitivamente submetida à ética, à economia e à política. No caso da cultura baseada no mercado livre de bens genômicos, os modelos platônicos pré-rearranjo técnico se revelam potencialmente inferiores, exatamente porque são identificados como meros produtos do acaso e não de uma ordem "perfeita" transcendente. Encurralase o absoluto desnudando-o de sua necessidade, iluminando, na realidade, sua miserável contingência. E contra os efeitos nefastos das contingências, a civilização ocidental lança seu "maduro" projeto baconiano que se estabelece como oferta da programação técnica de organizações superiores da matéria viva, mais apropriadas para as demandas do mercado da evolução humana. Aí repete-se a transcendência assustadora. Aparentemente, a miséria ontológica estrutural do ser humano parece contagiar a instância que até então era a portadora da dinâmica de perenidade, desmascarando sua condição de acaso. O "novo" paraíso de Adão será mais "adaptado" pois não estará preso (ou pelo menos, estará em menor escala) aos ditames da contingência (nova face da natureza criadora, mergulhada na humilhante categoria de objeto da técnica adâmica), e nessa medida, terá uma perfeição mais real e mais útil.

Mas diante de tamanha possibilidade de emancipação, por que tamanho pavor, afinal? O abismo ontológico no plano religioso profundo pode ser identificado com o desconforto do ser humano em aceitar a proposta de Milton feita a Adão (legislar livremente sobre o jardim da des-graça) e a responsabilidade metafísica que tal proposta acarreta, ${ }^{13}$ aliás, o mesmo peso que faz (em menor grau) toda uma cultura contemporânea baseada no projeto existencial da "adolescência eterna, reativa ao vazio metafísico" recusar as agruras da idade adulta em todos os planos, mergulhando a sociedade em delírios narcíseos (a atitude narcísea é essencialmente infantil). Outro argumento também relacionado mais diretamente com explícitas dimensões ontológicas é a afirmação de que a manipulação gênica seria contra a condição humana. Mas afinal, o que vem a ser esta condição humana senão a de combater a natureza que nos devora?

$O$ fato da natureza passar a sofrer das mesmas mazelas humanas (isto é, sua intencionalidade duvidosa) pode ser seguramente uma outra referência do medo, materializado 
em idéias simplistas como "exércitos nazistas indestrutíveis". Aqui, o infantil enredo cyberpunk (o cenário é muito mais próximo, na realidade, do livre e "democrático" mercado de bens de consumo, entregue às grandes companhias de seguros de saúde e às empresas como Celera Genomics, legítimos agentes do mercado de serviços e dessa arrasadora forma de medicina pré-natal) na realidade esconde a verdadeira face da trama política latente em discussões como o problema das patentes e a definitiva normalização jurídica do poder do capital sobre os códigos das (futuras) melhores formas genéticas de adaptação às demandas da evolução das espécies. Por outro lado, a simples determinação de que tais códigos seriam patrimônio público, ainda que representem um ganho, antes de tudo simbólico em relação à proposta (provavelmente vitoriosa em maior escala) da patente privada, não representa um grande avanço uma vez que todas as relações políticas tendem a ser sustentadas em bases de custos econômicos, e a humanidade, além de ser, como bem definiu o filósofo francês Alain Finkielkraut (1996), uma construção conceitual já perdida, que apenas permanece enquanto resto do conceito, não detém o monopólio da violência econômica legítima. A tendência será a privatização dos instrumentos de poder - assim como, por exemplo, privatizam-se os instrumentos de ação pública via a simples prática da corrupção ou de sua forma "sublime", o lobismo - sobre a violência genômica legítima. Parece-me, portanto, que o aparente grande combate entre os partidários da privatização explícita e os defensores da propriedade pública (privatização implícita) tende a se esvaziar quando se tratar do acesso efetivo às técnicas genômicas, principalmente em sociedades como a brasileira, em que o Estado e a sociedade são suicidas. Todavia, tal embate pode representar seguramente um maior acesso democrático às técnicas genômicas uma vez que algumas sociedades, menos reféns da miséria política que assola países como o Brasil, assimilarem esse modo radical de emancipação aos seus programas político-sociais, em vez de ficarem paralisadas diante do imaginário aterrorizado pelo abismo ontológico que ela representa. Tal atitude é diretamente dependente de uma ampla democratização da reflexão sobre a engenharia genética, uma prática reflexiva que seja livre da consciência "pecadora" e que sofre de pesadelos noturnos por ter mais uma vez apostado na serpente. $O$ terror aqui assume sua clara consistência política, portanto paralisa a capacidade do senso comum para perceber a revolução em curso, e, para isso, nada melhor que o investimento em imaginários infantis apocalípticos que apresentam a engenharia gené- tica como algo "opressor" por ser "antinatural". Quem permanecer na recusa da revolução genética, em defesa de uma natureza inexistente, será como um nômade diante da revolução da agricultura, vagando no vazio da nova hierarquia social do Ser (social e psicológico), como um pária ontológico.

Ainda que, na maioria das vezes, toda essa questão seja tratada dentro de um cenário "futurista" néon, na prática provavelmente se dará de um modo muito mais banal. $\mathrm{O}$ filme Gattaca, já citado, aqui também serve como indicação temática: as decisões deverão se dar muito mais no plano privado dos afetos e arranjos familiares. Casais possuidores de bons planos de saúde irão aos seus laboratórios, em manhãs cheia de sol e de amor (e dos "melhores" planos para a futura criança), aconselhados por um consciencioso profissional da área de pré-natal e lá completarão a seleção interna de seus patrimônios genéticos. Não será muito diferente dos passos, em breve arcaicos, que ocorrem hoje quando já somos munidos de formas precárias de terapias (preventivas) genéticas. Aliás, de certa forma, a terapia genômica será apenas uma forma poderosa de medicina preventiva pré-natal. Mesmo os mais amantes dos "delírios" em favor do acaso, terão mais dificuldades - dúvidas existências ${ }^{14}$ - em correr riscos quando contarem com formas seguras de evitar sofrimentos biológicos para sua prole. Evidentemente, toda essa sistematização produzirá um poderoso vetor de paranóia e discriminação, inclusive no já precário mercado do amor, levando os consumidores de parceiros love hunters ao delírio maior estilizado no filme Gattaca e seu genetic i.d. Em breve, toda a identidade genética ${ }^{15}$ - sem paranóias muito estranhas - será assimilada ao cabedal cotidiano de "dados" que um adulto consciente tem de levar em conta quando se lança à pesquisa mercadológica dos afetos, principalmente quando envolve a "sagrada" idéia de compromisso por amor. Pais conscienciosos, evidentemente, serão obrigados - movidos pelos "melhores sentimentos" produzidos por uma educação elaborada, típica das elites conhecedoras do que "há de mais novo" em termos de sofisticação dos modos de adaptação às necessidades do "mercado de futuros"- a introduzir essa variável nos diálogos esclarecidos com seus jovens filhos e filhas (produtos da "carinhosa" programação genética, evidentemente), que como sempre, tenderão a fazer escolhas pouco pensadas e por isso mesmo, de grande risco (genético).

Todavia, uma outra variável (ainda mais aterrorizante para os descendentes angustiados de Adão) tem de ser introduzida nesta discussão acerca dos padrões de com- 
portamento dos casais reprodutores, sejam eles de fato binucleares ou mononucleares (usuários de bancos de espermatozóides ou óvulos): a alteração do critério legítimo de filiação. Hoje em dia, e ainda enquanto a filiação se der em bases "homogenéticas" (mesmo quando a programação interna ao patrimônio genético dos agentes for assimilada pelo comportamento sistemático da reprodução geneticamente assistida), a filiação é um evento integrado ao que poderia definir como "campo biológico estrito" - salvo nos casos de adoção que representam uma exceção à regra. Isso pode ser alterado desde que, genes desejados e úteis (isto é, os recursos genômicos existentes em um dado momento no mercado) possam ser aceitos juridicamente como parte da procriação geneticamente assistida, passando a filiação a ser redefinida por porcentagens homogenéticas ou de documentos representativos da "compra" legítima de patrimônios heterogenéticos que deverão garantir a melhor adaptação do amado filho ou da querida filha. A sistematização desse procedimento levará a sociedade a um rigoroso esforço jurídico para legitimamente redefinir as bases da hereditariedade familiar. Por exemplo, em uma eventual separação, o parceiro que tiver comprovado a "compra" do maior ou mais definitivo (inclusive em termos financeiros, talvez) componente heterogenético introduzido na criança, terá provavelmente um argumento de peso para a sua guarda. ${ }^{16}$ Vê-se aqui uma radical transformação da noção social de filiação, na qual o privilégio, antes dado à "continuidade" biológica, cede espaço aos processos jurídicos e "estritamente sociais" (artificializantes) de determinação das identidades e das legitimidades. Biologiza-se a sociedade na mesma medida em que se socializa a biologia: só que o biológico se torna commodity enquanto o social se radicaliza como critério (artificializante). É exatamente esse o processo de relativização ao qual se fazia menção anteriormente: os critérios são cada vez mais móveis e civilization-dependent. Dessa forma, seria possível se sugerir que todo o processo "natural" de adaptação da espécie (de todas as espécies, na realidade) torna-se função da sociedade civilizada e tecno-instrumental, e a ecologia genética da espécie, provavelmente, irá se tornar uma obviedade, na linha das decisões que definem as políticas (nos dois sentidos do termo) de biodiversidade. ${ }^{17}$

A relação entre a violência genômica legítima e o mercado de trabalho é algo já bastante evidenciado. A tendência deverá ser a assimilação progressiva dessa forma sofisticada de violência adaptativa aos processos já em curso de identificação de recursos humanos. Evidentemente que legislações poderão buscar formas de atenuar tal assimilação. Todavia, são tentativas que devem ocorrer dentro de um quadro já avançado de instalação das chamadas "formas de flexibilização" - legitimização definitiva da violência do capital sobre o trabalho - da alocação de recursos humanos. Assim sendo, o vetor aponta mais para uma pura e simples assimilação pacífica que para a sua inviabilização, reproduzindo nesse processo específico o movimento geral de cada sociedade e seus mecanismos (ativos ou não) de proteção dos indivíduos quanto à violência estabelecida por parte do capital contra o trabalho, isto é, a violência propriamente econômica da genômica tenderá a se ajustar aos quadros (ou vícios) já existentes em cada sociedade, acirrando, todavia, um agravamento das tensões preexistentes na estrutura. Por outro lado, os integrantes do mercado de trabalho deverão se adaptar na mesma linha de preocupações a ser apresentada pelos reprodutores biológicos. Assim como se deve aprender línguas estrangeiras, o indivíduo em busca de um maior grau de adaptação deverá investir no ajuste genômico de seus descendentes assim como no próprio, neste caso por formas paliativas de redução de fenótipos indesejáveis. A evolução de tal assimilação para atitudes discriminatórias e modos de funcionamento na base de "castas gênicas" pode ser um dos estágios no início do processo. Entretanto, com o aumento gradativo do consumo, via ampliação do acesso aos recursos, o que de início pode parecer uma "casta" voltará à "normalização" pela racionalidade do mercado: ninguém pensa no enorme contingente de pessoas que morrem de fome diariamente no mundo como uma "casta" legítima de vítimas que têm o direito de reivindicar o que lhes é negado pelo mercado, nem como vítimas de uma discriminação "étnica", mas simplesmente como uma condição normal do processo de adaptação das "coisas". Brevemente teremos "autoridades genômicas" - semelhantes, ainda que com maior consistência científica, às "autoridades monetárias", esta falácia contemporânea - esclarecendo como os recursos genéticos são em si democráticos e "apolíticos", e como os indivíduos que deles não fazem uso são vítimas da própria "culpa" ou atavismo comportamental. A usual metáfora "naturalista" lançada para neutralizar a conscientização política poderá ser bastante útil e, a menos que percebamos que o principal sentido filosófico da genômica é a própria dissolução da natureza, permaneceremos presos a esses discursos que absurdamente buscam o refúgio na pobre natureza para suas verdadeiras raízes ideológicas, históricas e sociais. ${ }^{18}$ É exatamente em 
momentos como esses que a decadência ontológica da natureza gerada pela genômica no plano filosófico deve ser trazida à luz e tornada compreensível para o senso comum: o sentido verdadeiramente político de toda essa "história da Natureza" saltará então aos olhos. E se existe uma "história" é porque algum processo de relativização de alguma forma se deu. Civilizar é um modo específico de declinar a ação histórica. Com a morte dessa natureza, tudo se humaniza e se torna objeto social e político. Evidentemente "escolher cansa" e uma resistência cega permanecerá ignorando cinicamente o processo em curso de dissolução. É interessante perceber como, ao lado de tal revolução genética, os discursos naturalizantes da história permanecem ativos. Será possível identificar aí um processo de alienação semelhante ao papel político-social muitas vezes desempenhado pela religião: a pura e simples crença em uma natureza que legislaria via o (suposto, mas irreal) acaso, passa a ser o poder incognoscível que, eternamente latente no velho lamento da orfandade metafísica moderna, permanece como resíduo que legitima o pavor diante do risco estrutural que caracteriza a aventura do conhecimento - o medo de Fausto e de seu "pai" Adão. A idéia corriqueira de que grandes "desgraças" acontecerão devido à genômica é, em muito, fruto desse resquício teológico (e teleológico) de que forças indomáveis (O Sagrado) permanecem retendo o sentido das coisas. Convivemos diariamente com desgraças geradas pelo modelo econômicosocial que abraçamos e jamais consideramos o próprio modelo como a desgraça. Voltando ao diálogo com Sloterdijk, parece que sem dúvida o nazismo prestou um grande serviço ao imaginário "moral" do Ocidente ao dar uma suposta definitiva localização ontológica e "moralgeográfica" do mal, poupando-nos o desconfortável trabalho intelectual e afetivo de perceber o quanto de normal, banal e racional ${ }^{19}$ teve a aventura nazista.

Na realidade, parece-me que o caráter mais marcadamente criminal da revolução genética acontecerá dentro dos padrões definidos pelo sociólogo espanhol Manuel Castels (1999) como "conexão perversa". Grosso modo, essa "conexão" se caracteriza pela perfeita harmonia entre o comportamento do capitalismo globalizado e estabelecido em redes e o modus operandi das redes internacionais de crime organizado, empresas que por sua selvagem habilidade em operar com velocidade, flexibilidade e violência, estão na proa da atitude mais bem sucedidamente adaptada a uma sociedade (des)regrada pelas ausências de regras e submetida ao império dos desejos nas mais diversas escalas. Os recursos genômicos se enquadram total- mente na linha de produtos que a "conexão perversa" comercializa, aliás, toda a rede de comércio ilegal de órgãos humanos poderá servir já como uma pré-especialização para a identificação de recursos humanos logísticos alocados para lidar com a sofisticada mercadoria biológica. Um outro fator que poderá agravar uma tendência à "conexão genômica" é a demora da sociedade legítima para atuar sobre a revolução genética de modo não-cínico. Aqui também o horror ontológico pode fazer seu estrago, pois poderá abrir espaço para uma infeliz criminalização de alguns recursos genômicos mais agressivos tecnologicamente, ao potencializar o cinismo intelectual.

Outro terreno em qualquer reflexão que pretenda enfrentar intelectualmente a revolução genética são os campos da fisiologia e psicologia. Não se pretende abordar aqui a longa e árdua discussão sobre o determinismo (ou não) presente nos modelos antropológicos genomicsoriented. Isso não implica supor que tal objeto de reflexão seja inválido, mas simplesmente que ele é uma superespecialização na reflexão geral sobre a revolução genética e não é o primeiro na escala de preocupações de uma reflexão que pretenda iluminar o "senso comum" quanto ao horror ontológico paralisante. Evidentemente, o palco da controvérsia entre deterministas e antideterministas será fundamental na reflexão sobre a revolução em curso. ${ }^{20}$ Todavia, não se pode pensar que a revolução genética dê a "vitória" tão evidente para qualquer um dos "lados", simplesmente porque se tenderá a assimilar os recursos genômicos da gama de insumos que lançamos mão no processo de adaptação, e nessa medida os "genes" estarão fortemente submetidos às relações sociais e aos atores, eles mesmos devorados pela bioquímica genômica de consumo. Com isso, quer se apontar para a circularidade latente nessa controvérsia acerca do determinismo. Sem dúvida o patrimônio genético é um exemplo do que poderíamos chamar de "contexto forte", entre outros inúmeros, na condição humana. ${ }^{21}$ Mas supor uma autonomia forte do ser humano, à semelhança dos iluministas utópicos pré-crítica romântica alemã, é pura ingenuidade filosófica. Carregar (prioritariamente) na discussão sobre o determinismo - supondo ser esta a grande issue no advento da genômica - é mais uma forma de escamotear a artificialização da natureza em curso na normalização da práxis genômica. Qualquer processo de observação empírica - assim como qualquer modelo terapêutico associado ou decorrente dela - do comportamento e da trama de dramas humanos aprenderá a lidar com o "contextualismo genômico", da mesma maneira que 
tem aprendido a lidar com o "contextualismo farmacológico", por exemplo. Assim sendo, a fisiologia e a psicologia tenderão, neste modo de ver, a lidar "pontualmente" com a dissolução da natureza, isto é, dentro de seus campos específicos de observação e sem necessariamente tomar consciência de tal ruptura ontológica. Não parece que farão resistência significante ao processo em curso, e também insistirão em abordagens que iluminarão "microscopicamente" o processo, e assim sendo não facilitarão a vida do consumidor na melhora de sua "acuidade visual ontológica". As alterações fisiológicas ou psicológicas - como, por exemplo, a elevação do "coeficiente genômico" da população - deverão fazer parte - como já o fazem - do próprio processo de normalização do paradigma genômico.

Desse modo, pode-se pensar que para uma abordagem realmente esclarecedora da dimensão do que está em jogo no tema da revolução genética, faz-se necessário antes de tudo o enfrentamento deste tema em chave filosófica. É muito provável que a passagem se dê diretamente das discussões chamadas de "éticas" (que usualmente perdem de vista o problema ontológico do horror ao qual já se fez referência) para os procedimentos técnico-jurídicos, sem esclarecer suficientemente a ruptura ontológica fundamental que se processa diante de nossos olhos. Sofreremos os efeitos de tal ruptura ontológica de qualquer modo. Para além dos efeitos inevitáveis que uma ruptura dessa magnitude terá sobre a totalidade da sociedade, esse momento poderia se transformar em uma rara oportunidade para perceber que estamos mais uma vez, assim como nossos antepassados já estiveram, em profundo contato com movimentos viscerais do Ser. Lembrando pela última vez o historiador Mircea Eliade, Ser implica indagação do sentido último (ou sua total ausência) das coisas. O fenômeno sobre o qual se tentou lançar alguma luz, a dissolução da natureza pela genômica de consumo, é na realidade um diálogo radical e absolutamente contemporâneo com o Ser. Pelo diálogo, elabora-se o terror que tal vertigem envolve. Desde os primórdios sabe-se que nossa espécie elabora seu terror estrutural produzindo cultura. Faz parte necessariamente da ruptura atual tanto o terror que ela gera, como o possível diálogo com este mesmo terror. Palavras ditas a um coração angustiado podem evitar que ele seja devorado pelo medo. Quem silenciar, ficará cego.

\section{NOTAS}

E-mail do autor: 1fponde@zaz.com.br
1. Ainda que no capítulo especialmente dedicado à biotecnologia se peque pelos mesmos erros metodológicos e de conteúdo a que faremos referência na seqüência, o livro de Roger Shattuck (1998), é uma interessante exposição introdutória, ao alcance do leitor brasileiro que (infelizmente) ainda não lê inglês, sobre o caráter estrutural de risco do conhecimento a que fazemos menção aqui.

2. Infelizmente, é comum uma certa incompreensão por parte dos técnicos em ciência laboratorial da amplitude dos desdobramentos de suas (pequenas) atividades diárias para a sociedade em geral, levando-os muitas vezes a simplesmente desconhecerem tais desdobramentos ou pensarem que se tratam de produtos delirantes de ficção. Um pouco de cultura histórica aplicada às ciências naturais seria interessante a fim de recuperar um pouco da perspectiva histórica a que fazem referência autores como (entre outros) Thomas Kuhn (1987), ou mesmo um maior trato com a clássica literatura de ficção científica como Júlio Verne e outros.

3. Este problema do cinismo será novamente abordado com a controvérsia Slotyerdijk/Habermas sobre a revolução genética.

4. Por tal dissolução não se pretende evidentemente dizer que as leis naturais deixam de existir mas simplesmente que a natureza, enquanto lugar ontologicamente oposto à técnica ou cultura, perde sua consistência geográfica. Essa clássica oposição, grosso modo, herdada da Grécia, perde a validade porque a natureza pode ser programada e organizada exatamente pelo conhecimento técnico que adquirimos sobre suas leis mais íntimas. Assim sendo, dissolve-se como agente absoluta alheia a intenções e necessidades humanas e passa a ser devassada pelo poder humano de transformação técnica.

5. Exemplo típico do "cinismo": escamoteia-se a verticalidade e horizontalidade do problema colocado pelo próprio enredo do filme via uma solução "Cinderela". 6. Sobre tal controvérsia seria interessante ver o Caderno Mais! (Folha de S. Pau1o, 12/10/1999).

7. Neste aspecto, foram de grande valia como defesa da posição de Sloterdijk os textos publicados pelo intelectual francês e judeu, Bernard Henry-Levy: quem mais do que um judeu, diante da paranóia paralisante do nazismo, teria capital simbólico para reafirmar e esclarecer as "perigosas reflexões" do alemão Sloterdijk?

8. Mais especificamente, o projeto humanista (emancipação humana via uso de sua razão natural) veria esse aperfeiçoamento "assustador" como fruto da revolta renascentista e radicalizada pelo Iluminismo baseada na idéia da plena assunção do ser humano de sua condição de órfão de um Pai silencioso, inútil e injusto.

9. Sobre isto, já é possível ver as sínteses fantásticas que andam por aí a tratar de algo que seria uma "cabala genética".

10. Libertando-nos do pensamento mágico como cadeia de argumentos que dariam conta dos fenômenos naturais.

11. Daí os comentários típicos (e rasos) quando se fala em engenharia genética, de que surgirão "modismos" nas cores dos olhos e coisas semelhantes. Para além do excesso "ficção científica hollywoodiana", que serve de horizonte em tais reflexões simplistas, existe a consciência latente por parte do senso comum das fronteiras em jogo no processo "civilizador da matéria". Com a biotecnologia genética, a matéria viva inteligente se liberta do domínio exclusivo dos "cegos instintos atômicos" e penetra as infinitas possibilidades dos arranjos técnicos, culturais e imaginários dos seres humanos.

12. O Homem passa a ser, seguindo a fala de Protágoras, a medida também da Natureza.

13. Trata-se do problema do medo diante da orfandade metafísica.

14. No início da sistematização do consumo legítimo, provavelmente a terapia genômica se converterá em mais uma das infinitas causas de conflitos maritais.

15. O termo "identidade" aqui se refere, ambiguamente, tanto à identidade pessoal psicossocial (agora também definida em termos genéticos) quanto ao RG.

16. Evidentemente que tal fato integra-se às variações psicossociais que vêm acontecendo no comportamento dos pais quanto ao cuidado dos filhos, isto é, mais e mais os papéis de "pai" e "mãe" se distanciam da relação direta com as figuras biológicas de "pai" e "mãe". A crescente revolução das mulheres para se libertarem da "obrigação solitária" de cuidar da cria pode vir a ser um agravante na complexidade nas sentenças jurídicas que envolvam a decisão da guarda das crianças em um futuro próximo.

17. Insisto que nada disso implica um imaginário Admirável mundo novo.

18. Portanto culturais e não-naturais.

19. No sentido mais instrumental que possa ter este conceito.

20. Seria interessante lembrar aqui a importância, por muitos desconhecida, da controvérsia do século XVII sobre a relação entre graça divina e natureza humana (agostinianos $\mathrm{x}$ jesuítas) quanto à economia moral do comportamento humano 
em todo o processo de decadência da consistência racional dos vocabulários teológicos - como dito anteriormente ao citar Richard Rorty - no Ocidente. Um dos principais produtos de tal controvérsia é exatamente a derrocada de Deus como integrante consistente do diálogo ontológico (moral e científico) nas sociedades filhas do Iluminismo francês.

21. Aliás, reconhecer tal força é mais que esperado, se pensarmos que o materialismo é nosso "paradigma normal".

\section{REFERÊNCIAS BIBLIOGRÁFICAS}

CASTELS, M. Fim do milênio. Rio de Janeiro, v.3, Paz e Terra, 1999 (Col. A era da informação: economia, sociedade e cultura).

CHATWIN, B. Anatomia da errância. Lisboa, Quetzal Editores, 1997.

DESCARTES, R. Meditações metafísicas. São Paulo, Ed. Abril, 1983 (Coleção Pensadores).
ELIADE, M. A history of religious ideas. Chicago, The University of Chicago Press, 1978.

ELIAS, N. El Proceso de la civilización. México, Fonde de Cultura, 1993.

. A sociedade dos indivíduos. Rio de Janeiro, Jorge Zahar, 1994.

FAYE, E. Philosophie et perfection de l'homme, Paris, J. Vrin, 1998.

FINKIELKRAUT, A. L'humanité perdue. Paris, Gallimard, 1996.

FOLHA DE S. PAULO. Caderno Mais, 12/10/1999.

GÖETHE, J.W. Fausto. São Paulo, Edusp, 1981.

KUHN, T. Estruturas das revoluções científicas. São Paulo, Perspectiva, 1987.

MILTON, J. Paradise lost. Londres, s.d. (publicado no séc. XVII).

RORTY, R. Contingência, ironia e solidariedade. Lisboa, Editorial Presença, 1992.

SHATTUCK, R. O conhecimento proibido. São Paulo, Cia. das Letras, 1998.

WILSON, E. O conscilience. Nova York, Alfred A.A Knopf, 1998. 